\title{
EFEKTIFITAS METODE PEMBELAJARAN DONGENG DALAM MENINGKATKAN KEMAMPUAN LITERASI ANAK PADA JENJANG USIA SEKOLAH DASAR
}

\section{Patimah}

\begin{abstract}
ABSTRAK
Mendongeng merupakan batu loncatan penting dalam membentuk seorang jenius. Mendongeng memicu kekuatan berpikir yang super, yang melepaskan per-per imajinasi seorang jenius. menurut ahli psikologi anak, pertumbuhan mental seorang anak berjalan sangat cepat, terutama sampai anak berusia enam tahun, sampai umurnya enam tahun, kecepatan belajar anak bagai kuda yang berlomba dalam pacuan. Setelah melewati usia ini, kecepatan belajar anak akan menurun, dan lebih mendatar.

Guru yang telah terbiasa menggunakan metode mendongeng (berbeda dengan ceramah) pada saat proses KBM pada umumnya pasti memiliki siswa yang berkemampuan literasi yang baik dibandingkan dengan guru yang hanya mengajar dengan cara konvensional di dalam kelas.Kebiasaan yang di timbulkan dari aktivitas mendongeng mampu memberikan banyak dampak positif terhadap kemampuan literasi siswa baik kemampuan membaca, menulis dan berbicara.
\end{abstract}

\section{Kata Kunci : Dongeng, Psikologi Anak, Kemampuan Literasi}




\section{A. PENDAhuluan}

Kondisi pendidikan Nasional dari waktu ke waktu mengalami dinamisasi. Perubahan-perubahan yang terjadi pada dunia pendidikan tidak lain untuk memperbaiki proses berjalanannya pendidikan Nasional. Melalui kewenangan yang dimiliki pemerintah beruasaha senantiasa memberikan kebijakan yang sesuai dengan kondisi dan kebutuhan pendidikan Nasional dalam upaya meningkatkan mutu.

Fase awal setelah kemerdekaan bangsa Indonesia pendidikan yang dirasakan oleh masayarakat masih sangat kurang. Hal ini dikarenakan fokus pemerintah berpusat pada bidang perbaikan ekonomi. Budaya Literasi masayarakat pada masa itu sangat minim, hanya masyarakat kalangan elit saja yang memiliki kesempatan untuk menikmati pendidikan.

Fase orde baru sampai reformasi pendidikan bangsa Indonesia mengalami perbaikan yang sangat signifikan. Hal ini ditandai banyaknya warga Negara dari Negara tetangga yang menimbah ilmu di Indonesia. Budaya literasi masyarakat pada saat itu mengalami peningkatan.

Pada abad 20 pendidikan bangsa Indoensia memasuki era baru. Kemajuan teknlogi mewarnai proses berlangsungnya pendidikan. Kemajuan teknologi ini sayangnya tidak diikuti kemajuan dalam bidang pendidikan. Peningkatan mutu pendidikan Nasional kalah dengan peningkatan mutu pendidikan Negara tetangga. Budaya literasi masyarakat Indonesia tertinggal jauh jika dibandingkan dengan Negara berkembang lainnya. Berdasarkan penelitian UNESCO 2012 (setiap lima tahun) yang menyebutkan indeks minat baca di Indonesia baru mencapai 0,001. Artinya, setiap 1.000 penduduk, hanya satu orang saja yang memiliki minat baca. Angka UNDP juga mengejutkan bahwa angka melek huruf orang dewasa di Indonesia hanya 65,5 persen saja. Sedangkan Malaysia sudah 86,4 persen. ${ }^{1}$

Pendidikan pada abad 20 mengalami banyak tantangan. Selain dalam bidang teknologi, pun pendidikan Nasional dituntut untuk bisa menyajikan sistem

\footnotetext{
${ }^{1}$ http://www.antaranews.com/berita/462239/psikolog-stimulasi-kemampuan-literasi-sejak-dinipenting
} 
pendidikan yang mampu melindungi nilai-nilai karekter Bangsa dari pengaruh westerenisasi serta pendidikan bangsa ini dituntut untuk dapat menciptakan budaya literasi bagi masyarakat.

Membangun budaya literasi pada masyarakat yang belum memiliki keasadaran pendidikan tinggi bukanlah persoalan yang mudah. Dibutuhkan kerjasama anatara pemerintah selaku pembuat kebijakan dengan para guru selaku pelaksana pendidikan serta masyarakat yang dalam hal ini adalah para orangtua selaku guru para siswa di rumah.

Membangun suatu hal memang idealnya harus bermula dari dasar. Dalam hal ini proses penanaman budaya literasi sejatinya dikenalkan sejak dini. Jenjang pendidikan dasar ( SD/MI) biasanya proses pembiasaan literasi yang dilakukan sebagian besar adalah bercerita dan membaca sebagian kecilnya adalah kegiatan menulis. ${ }^{2}$

Oleh karena itu sudah sewajarnya jika seorang guru yang mengajar di SD/MI dituntut untuk memiliki keterampilan mendongeng. Mendongeng merupakan salah satu cara untuk mengenalkan budaya literasi kepada siswa. Dengan metode mendongeng juga akan terbangun kedekatan persuasif antara guru dengan siswa. Hal ini jika tejadi tentu akan mempermudah berlangsungnya proses KBM. Siswa yang sudah terbiasa mendengarkan dongeng akan tumbuh keinginan untuk membaca buku.

\section{B. METODE PEMBELAJARAN DONGENG}

Pengertian Mendongeng: Menceritakan kembali cerita-cerita yang telah terjadi.

\section{(Kamus Besar Bahasa Indonesia, Balai Pustaka)}

"Yang Paling Indah pada masa kanak-kanak adalah ( Seolah-olah) semuanya merupakan sebuah keajaiban" (G.K. CHESTERTON)

Mendongeng merupakan batu loncatan penting dalam membentuk seorang jenius. Mendongeng memicu kekuatan berpikir yang super, yang melepaskan per-per imajinasi seorang jenius. menurut ahli psikologi anak, pertumbuhan mental seorang

\footnotetext{
${ }^{2}$ Shauqi, akhmad. "upaya meningkatkan keterampilan membaca siswa melalui pendekatan whole language. Gorontalo.2015
} 
anak berjalan sangat cepat, terutama sampai anak berusia enam tahun, sampai umurnya enam tahun, kecepatan belajar anak bagai kuda yang berlomba dalam pacuan. Setelah melewati usia ini, kecepatan belajar anak akan menurun, dan lebih mendatar. (Suci. 2015 : 66)

Sebelum pendidikan si anak dikemas dalam bentuk formal, orang tua, atau kakek dan nenek, biasanya menjadi guru si anak. Dahulu kala, pendidikan, secara tidak langsung, tetapi dengan cara yang sangat bermakna, diterapkan melalui mendongeng. Sekelompok anak-anak akan duduk mengelilingi api unggun, dibawah sebatang pohon, dan seorang dewasa akan menceritakan sesuatu yang sangat memikiat, dan menarik perhatian. Kemudian, tulisan mulai memberikan pengaruh pada literatur lisan tradisional ini.

Bahasa dongeng lebih bermain pada imajinasi. Oleh karena itu, siswa tidak mudah mengantuk. Kalaupun ada nasehat pendidikan atau sindiran yang disampaikan melalui dongeng, orang tidak langsung merasa dinasehati atau disindir. Bahkan, siswa diminta menilai sendiri sebuah kebenaran atau pendidikan dalam dongeng yang didengarnya. Dalam pelajaran Bahasa dan Sastra semisal mengarang, ini tentu sangat membantu siswa. Bagaimana misalnya meneruskan sebuah cerita yang diperdengarkan kepada siswa, bagaimana siswa menemukan alur/ plot, tema, amanat, dan sebagainya, dalam metode mendongeng sangat dapat membantu.(Herman RN, Harian Serambi Indonesia, 10 Juli 2007)

\subsubsection{Manfaat mendongeng untuk peningkatan kognitif anak}

ADA beberapa manfaat mendongeng bagi anak, diantaranya ${ }^{3}$ :

a. Memicu kekuatan berpikir

Semua cerita yang baik, memiliki alur yang baik. Alur cerita anak-anak sebaiknya sederhana, karena karakter atau alur cerita yang terlalu rumit, akan membuat anak bingung. Sebuah dongeng sebaiknya membawa pesan moral berisi harapan, cinta, dan keberhasilan, tanpa mengguruhi. Tujuan utama pendongeng yang

${ }^{3}$ Shakuntala Devi. 2002. Bangunkan Kejeniusan Anak Anda. Jakarta: Gramedia 
baik adalah menceritakan dongeng yang baik. Sebuah cerita harus bisa, secara sederhana tetapi efektif, mendorong rasa ingin tahu. Apa yang terjadi kemudian? Kemana dia pergi? Apa yang dilakukan? Ketika cerita berlanjut, anak akan terbawa oleh arus dan kegairahan cerita. Kemudian, ketika cerita mencapai puncaknya, anak akan gembira. Kemungkinan besar, ia akan meminta Anda menceritakan kembali cerita yang sama, berulang-ulang. Dia sudah tahu, bagaimana ceritaberakhir tetapi itu tidak akan mengurangi minatnya. Segerah saja, anak akan memperbaiki apabila anak melakukan kesalahanya. Dia akan melakukan apa yang terjasi selanjutnya. Anak anda akan tumbuh dan berkembang, bersama dongeng yang didengarkan. Dongeng merangsang dan menggugag kekuatan berfikirnya.

\section{b. Menciptakan Kebangkitan Visual}

Apa yang terjadi apabila Anda menonton bioskop? Layar bioskop akan terisi warna-warna dan gerakan-gerakan. Gambaran visual yang jelas dari karakter-karakter yang seolah-olah hidup, secara total berhasil menarik perhatian Anda. Mendongeng mempunyai efek yang sama, dengan perbedaan besar-perbedaan penting, yang merupakan keharusan bagi jenius kecil yang sedang berkembang. Kata-kata kuat yang penuh makna dan kaya arti, memutar bioskop di dalam otak si anak. Dalam mata pikirannya, anak melihat berkelebatnya gambar-gambar yang yang amat jelas. Rurdyard Kippling, penulsi dan penyair Inggris, mampu menciptakan gambaran gaib ini melalui prosa-prosanya yang kaya dan memikat, seperti yang tercermin didalam kalimat: Suara lecutan cambuk sapi, dan geritan roda kereta, suara api yang dinyalakan, dan makanan yang dimasak. Seorang anak bisa segerah membayangkan, suasana yang hidup dan sibuk disebuah perkemahan. Disamping itu, kreativitas anak akan terbangun oleh berbagai kemungkinan visual.

\section{c. Mengaitkan Kata-Kata dengan Gambar}

Saat mendongeng, bakat akrobatik suara kita akan sangat berguna! Bagaimana menirukan suara orang tua yang lemah dan bergetar, auman seekor singa, suara monyet yang gugup dan melengking. Pendeknya, Anda berusaha menghidupkan kata- 
kata yang dipilih si pengarang dengan sangat cermat. Selain kegembiraan dan kesenangan dalam mendengarkan, Anda juga mengasah pendengaran anak terhadap nuansa bunyi-bunyian. Kata-kata bisa jadi sangat mengagumkan apabila diucapkan dengan intonasi, dan ekspresi yang berbeda. Anda bahkan bisa menambah dengan gerakan pantonim sesuai dengan kejadian-kejadian di dalam cerita. Cara ini akan menarik anak, dan menambah elemen kegembiraan ke dalam proses pendidikan bunyi-bunyian memperdalam rasa visual, memberi dimensi tambahan pada bioskop di dalam diri anak.

\section{d. Memupuk Pengertian terhadap Orang Lain}

Anda tentunya ingin jenius Anda memiliki banyak pengetahuan yang berguna agar dia bisa memahami orang lain. Itulah manfaat mendongeng. Tokoh-tokoh di dalam bukucerita akan terasa hidup, apabila dibumbuhi kemampuan kemampuan membaca Anda yang mengagumkan. Anak akan bisa membedakan tokoh yang satu dari yang lain, bahkan mengenali ciri dari masing-masing tokoh. Setiap tokoh akan menjadi temannya. Barangkali dia lebih menyukai tokoh yang satu dibanding dengan tokoh yang lain. Tidak ada salahnya. Tetapi, sejak usia muda, anak akan memehami adanya perbedaan sifat. Bagi dia, tokoh-tokoh itu hidup, dan sama nyatanya seperti anda, orang tuanya. Dengan memahami tokoh-tokoh tersebut, anak akan memahami dirinya. Ini merupakan tahap dari proses pertumbuhan. Apabila pikirannya mampu membeda-bedakan, anak Anda akan menerima kenyataan, bahwa menyet yang nakal berbeda dengan singa yang garang. ${ }^{4}$

\subsubsection{Cara mendongeng yang efektif}

Siapa saja bisa mendongeng, tidak ada yang tidak bisa. Mulai dari Presiden sampai pengemis. Bahkan, maaf, orang cacat pun terkadang lebih bisa mendongeng dari pada kita yang normal, tinggal bagaimana caranya masing-masing yang sesuai dengan kemampuannya. Tetapi untuk bisa mendongeng dengan baik dan menarik

\footnotetext{
${ }^{4}$ Opcit.......
} 
tentunya tidak mudah. Agar kita bisa mendongeng dengan baik dan menarik (menurut cara kak Rico) kiat-kiatnya antara lain adalah :

a. Berdoa

Jangan lupa kita berdo'a terlebih dahulu sebelum kita mulai mendongeng karena ini paling penting dari yang lainnya. Sesiap apa pun kita mendongeng, sepintar apa pun kita mendongeng, tetap saja kita tidak boleh mengabaikan hal yang satu ini. Dengan berdo'a terlebih dahulu yakinlah bahwa insya Allah kita akan berhasil mendongeng dengan baik. Amin

\section{b. Mempersiapkan Cerita/Dongeng}

Siapkan cerita yang akan kita sampaikan, bisa kita karang sendiri atau kita gunakan cerita karya orang lain. Dongeng/cerita disarankan antara lain :

- Mudah kita kuasai

- Dapat menghibur dan memikat perhatian anak-anak

- Dapat mengembangkan imajinasi anak-anak

- Edukatif/mendidik

c. Memiliki Rasa Malu Terhadap Diri Sendiri \& Anak-anak

Idealnya dalam mendongeng, kita tentunya selalu menyampaikan nasehatnasehat yang ada dalam cerita kepada anak-anak. Oleh karena itu, sebaiknya kita juga harus punya rasa malu kepada diri sendiri dan anak bila diri kita sendiri tidak seperti apa yang kita nasehatkan kepada anak-anak.

d. Menyukai dan Menyayangi Anak-anak.

Pastikan bahwa kita menyukai dan menyayangi anak-anak, tanpa hal ini mustahil kita akan bisa mendongeng dengan baik. Sebab kalau kita sendiri kurang menyukai dan menyayangi anak, apa mungkin kita bisa sabar dan santun dalam menyampaikan cerita kepada anak-anak?

e. Mendalami dan Menghayati Cerita/Dongeng. 
Sebelum kita sampaikan ke anak-anak, kita harus terlebih dahulu dapat mendalami dan menghayati cerita. Dengan mendalami dan menghayati cerita, kita akan dapat lebih hidup dalam menyampaikan alur-alur cerita dan lebih ekspresif dalam bertutur kata.

f. Gunakan Kata-kata Yang Mudah Dipahami Anak.

Rasanya kita tidak mungkin dalam mendongeng menggunakan kata-kata yang tidak mudah dipahami oleh anak. Misalnya saja kita menggunakan kata 'biografi', 'profesi', 'kompensasi', dan lain sebagainya. Lebih sangat tidak mungkin lagi kita mendongeng di depan anak-anak berkebangsaan lain dengan menggunakan bahasa Indonesia, demikian pula sebaliknya.

g. Gunakan Karakter Suara Yang Sesuai Dengan Tokoh-tokoh Cerita.

Karakter suara pada setiap tokoh tentunya harus berbeda-beda dan sesuai dengan karakter tokoh masing-masing, sebab kalau tidak, kita tidak akan berhasil menyampaikan dongeng dengan baik. Contohnya, untuk memperagakan tokoh Nenek Sihir yang jahat tidak mungkin kita menggunakan karakter suara yang halus dan lemah lembut bak seorang peri yang baik hati.

\section{h. Gunakan Alat Peraga.}

Anak-anak biasanya akan tertarik sekali kalau kita mendongeng menggunakan alat peraga/properti. Alat peraga bisa saja berupa sebuah boneka atau benda-benda lainnya. Tetapi kalau kita tidak punya alat peraga, kita tetap dapat membuat anakanak tertarik dengan dongeng dengan cara membuat gerakan-gerakan ekspresif, enerjik, dan jenaka.

\section{i. Gunakan Ilustrasi Musik dan Efek-efekSuara.}

Dongeng yang kita sampaikan akan menjadi lebih hidup bila diiringi dengan musik ilustrasi dan efek suara. Hal ini juga akan semakin mempermudah anak-anak berimajinasi dan terbawa emosinya. 


\section{KEMAMPUAN LITERASI}

\section{TAHAPAN KEMAMPUAN LITERASI SISWA SEKOLAH DASAR}

Kemampuan literasi disesuaikan dengan jenjang kelas. Setiap tingkatan kelas pada jenjang sekolah dasar memiliki kompetensi literasi yang berbeda. Berikut adalah kompetensi yang harus dimiliki siswa sesuai dengan jenjang kelasnya masing-masing.

\begin{tabular}{|c|c|c|c|}
\hline Kelas & Membaca & Menulis & $\begin{array}{c}\text { Berkomunikasi } \\
\text { (berbicara) }\end{array}$ \\
\hline $\mathrm{I}$ & Mengeja bacaan & $\begin{array}{l}\text { Menyalin tulisan } \\
\text { dalam kalimat } \\
\text { sederhana }\end{array}$ & $\begin{array}{l}\text { Berbicara dengan bahasa } \\
\text { Indonesia dan Berani bertanya } \\
\text { dalam } \\
\text { kegiatan pembelajaran }\end{array}$ \\
\hline II & Membaca lancar & $\begin{array}{l}\text { Membuat kalimat } \\
\text { Sederhana }\end{array}$ & $\begin{array}{l}\text { Menceritakan dengan } \\
\text { singkat suatu peristiwa } \\
\text { atau pengalaman pribadi }\end{array}$ \\
\hline III & $\begin{array}{l}\text { Membaca dengan } \\
\text { lafal dan intonasi } \\
\text { yang tepat }\end{array}$ & $\begin{array}{l}\text { Membuat } \\
\text { paragraf dan teks } \\
\text { sederhana dan } \\
\text { Menulis surat } \\
\text { atau puisi } \\
\text { sederhana }\end{array}$ & $\begin{array}{l}\text { Membuat paragraf dan } \\
\text { teks sederhana }\end{array}$ \\
\hline IV & $\begin{array}{l}\text { Menemukan } \\
\text { pokok pikiran } \\
\text { dari suatu teks } \\
\text { yang dibaca dan } \\
\text { Mahir } \\
\text { menggunakan } \\
\text { kamus atau }\end{array}$ & $\begin{array}{l}\text { Menulis dengan } \\
\text { ejaan yang benar } \\
\text { dan Membuat cerita } \\
\text { atau karangan } \\
\text { sendiri }\end{array}$ & $\begin{array}{l}\text { Berani mengeluarkan } \\
\text { pendapat atau saran di } \\
\text { kelas dan Memberi petunjuk/ } \\
\text { pre`sentasi atau } \\
\text { pengumuman lisan }\end{array}$ \\
\hline
\end{tabular}




\begin{tabular}{|l|l|l|l|}
\hline & ensiklopedi & & \\
\hline V & $\begin{array}{l}\text { Mengerti isi pesan } \\
\text { berita ringan yang } \\
\text { berasal dari media } \\
\text { cetak }\end{array}$ & $\begin{array}{l}\text { Menulis dengan } \\
\text { penggunaan tanda } \\
\text { baca yang benar }\end{array}$ & $\begin{array}{l}\text { Melakukan wawancara } \\
\text { Sederhana dan Bermain peran } \\
\text { drama }\end{array}$ \\
\hline VI & $\begin{array}{l}\text { Mengumpulkan } \\
\text { informasi dari } \\
\text { berbagai referensi }\end{array}$ & $\begin{array}{l}\text { Membuat peta } \\
\text { Pikiran }\end{array}$ & Praktik berpidato singkat \\
\hline
\end{tabular}

\section{ASPEK KEMAMPUAN LITERASI}

- MEMBACA

\section{Definisi Membaca}

- Anderson:

Membaca adalah melafalkan lambang-lambang bahasa tulis.

- A.S. Broto:

Membaca adalah mengucapkan lambang bunyi.

- Henry Guntur Tarigan:

Membaca adalah proses pemerolehan pesan yang disampaikan oleh seorang penulis melalui tulisan.

- Poerwodarminto:

Membaca adalah melihat sambil melisankan suatu tulisan dengan tujuan ingin mengetahui isinya.

Dapat disimpulkan bahwa membaca adalah proses melisankan dan/atau memahami bacaan atau sumber tertulis untuk memperoleh pesan atau gagasan yang ingin disampaikan penulisnya. ${ }^{5}$

\footnotetext{
${ }^{5}$ Akmad shauqi. 2015. Upaya meningkatkan keterampilan membaca melalui pendekatan whole language. Sekolah guru Indonesia. gorontalo
} 


\subsubsection{Komponen Kegiatan Membaca}

Farida Rahim (2008: 12) menyampaikan bahwa kegiatan membaca terdiri dari dua komponen yaitu: a) proses membaca, dan b) produk membaca. ${ }^{6}$

\section{Proses Membaca}

Farida Rahim (2008: 12) menyampaikan bahwa proses membaca terdiri dari 9 aspek, yaitu sensori, perseptual, urutan, pengalaman, pikiran, pembelajaran, asosiasi, sikap, dan gagasan. Proses sensori visual menurut Farida Rahim (2008: 12) diperoleh dengan pengungkapan simbol-simbol grafis melalui indra penglihatan. Anak-anak belajar membedakan secara visual simbol-simbol grafis (huruf atau kata) yang digunakan untuk mempresentasikan bahan lisan. Kegiatan perseptual dijelaskan Farida Rahim (2008: 12) sebagai aktivitas mengenal suatu kata sampai pada suatu makna berdasarkan pengalaman yang lalu.Aspek urutan merupakan kegiatan mengikuti rangkaian tulisan yang tersusun secara linear, yang umumnya tampil dalam satu halaman dari kiri ke kanan atau dari atas ke bawah. Pengalaman merupakan aspek penting dalam proses membaca. Farida Rahim (2008: 12) menyampaikan bahwa anak-anak yang memiliki pengalaman banyak akan mempunyai kesempatan yang lebih luas dalam mengembangkan pemahaman kosakata dan konsep yang mereka hadapi dalam membaca dibandingkan dengan anak-anak yang memiliki pengalaman terbatas. Untuk memahami makna bacaan, pembaca terlebih dahulu harus memahami katakata dan kalimat yang dihadapinya.Kemudian pembaca membuat simpulan dengan menghubungkan isi preposisi yang terdapat dalam materi bacaan. Agar proses ini dapat berlangsung pembaca harus berpikir sistematis, logis, dan kreatif.

\footnotetext{
${ }^{6}$ Suci rahmadani. 2015. Upaya meningkatkankemampuan menceritakan kembali melalui metode mendongeng. Sekolah guru Indonesia. Gorontalo
} 


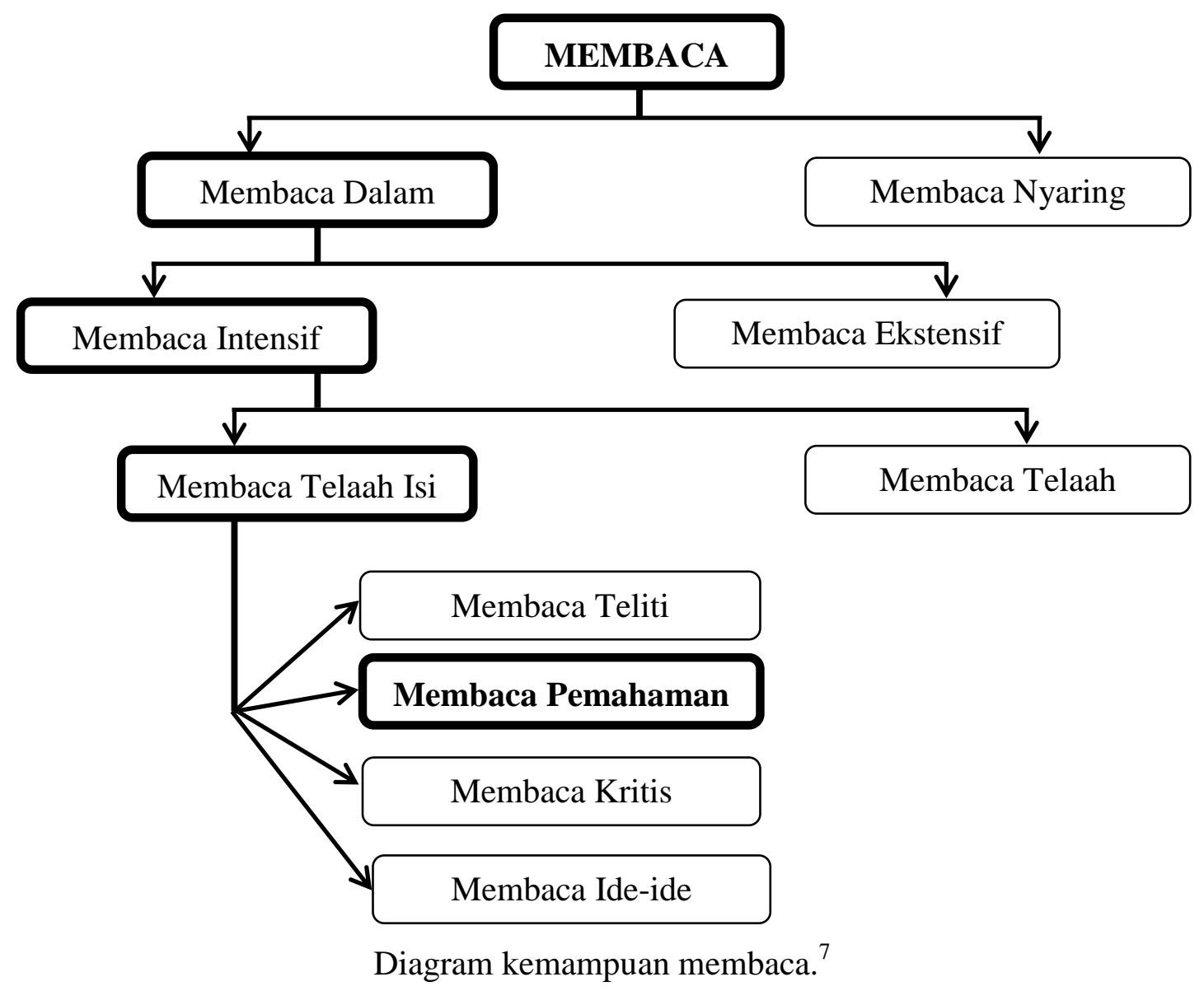

Metode mendongeng mampu meningkatkan minat membaca siswa siswa. Ketika guru mampu membiasakan pembiasaan mendongeng/bercerita secara bertahap rasa penasaran siswa terhadap cerita yang diceritakan akan menuntun siswa untuk mencari sendiri cerita tersebut. Hal ini hanya bisa dilakukan tentunya dengan siswa membaca sendiri buku cerita tersebut. Rasa penasaran siswa ini yang mampu dimanfaatkan oleh guru untuk mengarahkan siswa membaca. Kegiatan ini secara jangka panjang akan menumbuhkan budaya membaca anak serta budaya literasi siswa

\footnotetext{
${ }^{7}$ Opcit....
} 


\section{- MENULIS}

Menulis mempunyai peranan yang sangat penting bagi manusia. Menulis merupakan salah satu sarana komunikasi seperti halnya berbicara. Namun, dalam prakteknya penggunaan bahasa dalam menulis tidaklah sama dengan komunikasi lisan. Hal ini dikarenakan bahasa digunakan secara fungsional yaitu pemakaian bahasa sebagai media interaksi dan transaksi. Dengan demikian, kegiatan menulis menuntut kecakapan dan kemahiran dalam mengatur menggunakan bahasa, bekerja dengan langkah-langkah terorganisir, gagasan secara sistematis serta mengungkapkan secara tersurat.

Menulis sendiri bukanlah sesuatu hal yang asing bagi kita. Ada banyak manfaat yang dapat diambil dari menulis. Manfaat itu diantaranya dalam hal peningkatana kecerdasan, pengembangan daya inisiatif dan kreativitas, penumbuh keberanian serta pendorong kemauan dan kemampuan mengumpulkan informasi. Namun, aktivitas menulis atau sebagian orang menyebutnya mengarang tidak banyak menyukainya.

Graves dalam Yunus (2007: 14) menyatakan;

"Seseorang enggan menulis karena tidak tahu untuk apa dia menulis, merasa tidak berbakat menulis dan merasa tidak tahu bagaiamana harus menulis. Ketidaksukaan tak lepas dari pengaruh lingkungan keluarga dan masyarakat serta pengalaman pembelajaran menulis atau mengarang disekolah yang kurang memotivasi dan merangsang minat." 8

Berbicara tentang pengaruh lingkungan di sekolah terkadang masih banyak guru bidang studi bahasa Indonessia yang tidak mampu dalam menulis sebuah karangan sehingga dia kurang memotivasi dan merangsang minat siswa. Seperti pendapat Smith menyatakan; "pengalaman belajar menulis yang dialami siswa di sekolah tidak terlepas dari kondisi gurunya sendiri. Umumnya gurunya tidak dipersiapkan untuk terampil menulis dan mengajarkannya". 9

\footnotetext{
${ }^{8}$ Yunus Maulana. 2008. Mudahnya menulis, ayo menulis. Yogyakarta

${ }^{9}$ Opcit....
} 
Jadi dapat disimpulkan bahwa seorang guru juga harus mampu untuk memahami dan mengerti apa dan bagaimana mengarang itu. Sulit membayangkan seorang guru yang takut dan tidak suka menulis dapat melakukan hal itu. Padahal minat dan kemauan siswa belajar menulis tidak terlepas dari apa yang terjadi pada diri guru dan bagaimana dia mengajarkannya. Berdasarkan beberapa pendapat di atas dapat disimpulkan bahwa menulis adalah kesanggupan, kecakapan untuk mengungkapkan ide, pengetahuan, perasaan secara rasional dengan menggunakan bahasa tulis sebagai medianya.

Diantara empat kemampuan berbahasa yakni membaca, menulis, berbicara dan menyimak kemampuan menulis adalah kemampuan yang paling sulit untuk dikembangkan. Hal ini dikarenakan kemampuan menulis mampu berkembang hanya jika kemampuan membaca dan menyimaknya yang dimiliki individu sudah dapat dikatakan baik. ${ }^{10}$

\section{- BERBICARA}

Berbicara menurut Hendrikus merupakan titik tolak dan retorika, yang berarti mengucapkan kata atau kalimat kepada seseorang atau sekelompok orang untuk mencapai suatu tujuan tertentu (misalnya memberikan informasi/ memberi motivasi). Dengan kata lain, berbicara adalah salah satu kemampuan khusus pada manusia.

Menurut Djago Tarigan berbicara merupakan keterangan menyampaikan pesan melalui bahasa lisan, bicara diartikan sebagai kemampuan mengucapkan bunyi-bunyi artikulasi atau kata-kata untuk mengekspresikan, menyatakan, dan menyampaikan pikiran, gagasan serta perasaan.

Selanjutnya, Nurgiyantoro mengungkapkan bahwa berbicara adalah aktivitas berbahasa kedua yang dilakukan manusia dalam kehidupan berbahasa, yaitu setelah aktivitas mendengarkan, berdasarkan bunyi-bunyi yang didengar itu, kemudian manusia belajar untuk mengucapkan dan akhirnya terampil berbicara, dapat dikatakan berbicara merupakan suatu sistem tanda-tanda yang dapat didengar (audible) dan yang kelihatan (visible) yang memanfaatkan sejumlah otot tubuh manusia, demi

\footnotetext{
${ }^{10}$ Mubarak, hasan. Integrasi kemampuan berbahasa dalam proses pengembangan kemampuan menulis. Jakarta. 2010
} 
maksud dan tujuan gagasan atau ide-ide yang dikombinasikan. Berbicara merupakan suatu bentuk perilaku manusia yang memanfaatkan faktar-faktor fisik, psikologi, neurologis, semantik dan linguistik. ${ }^{11}$

Berdasarkan beberapa pendapat di atas, dapat disimpulkan bahwa berbicara merupakan kemampuan mengucapkan bunyi-bunyi artikulasi atau kata-kata untuk mengekspresikan, menyatakan dan menyampaikan pikiran, gagasan, perasaan, serta menyampaikan pesan melalui bahasa lisan kepada seseorang atau sekelompok orang untuk mencapai suatu tujuan tertentu. Yang perlu diperhatikan dalam berbicara adalah: (1) pelafalan bunyi, (2) penempatan tekanan, nada, jangka intonasi (3) penggunaan kata dan kalimat.

\section{Faktor-faktor yang Mempengaruhi Kemampuan Berbicara}

Kemampuan berbicara adalah kemampuan kita untuk berkomunikasi dengan orang lain, baik ketika ngobrol, presentasi, menyampaikan pendapat, eyel-eyelan (baca : berdebat) ataupun kegiatan lainnya. Kemampuan berbicara identik dengan penggunaan bahasa lisan yang tepat, sehingga pendengar dapat mengerti apa yang kita sampaikan. Selain itu, sikap dan pengetahuan menentukan waktu yang tepat untuk berbicara mendukung keberhasilan kita dalam berbicara.

Kemampuan berbicara dan bahasa anak erat kaitannya dengan kemampuan mendengar anak. Perkembangan bicara anak memerlukan pembinaan secara intensif, sesuai dengan taraf perkembangan fisik dan psikis yang lain. Kemampuan bahasa anak akan maksimal jika mendapat umpan balik yaitu mengontrol suara dan ucapannya sendiri melalui pendengarannya. Umpan balik yang mereka peroleh untuk mengontrol bicaranya hanya diperoleh secara visual, kinestetik dan gerak.

\section{Menurut Sadjaah dan Sukarja}

"perkembangan bahasa seseorang tak dapat lepas dari pengaruh berbagai faktor. Perkembangan bahasa dan bicara hanya akan berjalan dengan baik dan lancar bila didukung oleh faktor kesiapan atau kematangan". Lanjut Sadjaah dan

${ }^{11}$ Sukatmi.2009. Upaya Meningkatkan Keterampilan Berbicara dengan Media Gambar. Tidak Dipublikasikan. Skripsi Universitas Sebelas Maret. 
Sukarja menyatakan bahwa "Faktor-faktor yang mempe $\neg$ naruhi adanya kesiapan adalah faktor psikologis, faktor fisiologis, dan faktor lingkungan".

\section{Faktor Psikologis}

Faktor ini menyangkut aspek inteligensi, minat akan apa yang dilihat, dirasakan, dikehendaki di dengar dan perlu dikemukakan kepada orang lain. Kesanggupan meniru dan menyimpan apa yang di dengar, kesanggupan menata pikiran dan perasaan terhadap apa yang dimaksud.

\section{Faktor Fisiologis}

Faktor ini menyangkut masalah ketajaman pendengaran, susunan saraf yang berfungsi baik untuk mengendalikan gerakan otot-otot alat bica $\neg$ ra dan keadaan alatalat bicara yang baik.

\section{Faktor Lingkungan}

Faktor ini menyangkut masalah keterlibatan orang-orang yang berbahasa dan atau berbicara dengan baik, sedia memberi rangsangan berbi-cara kepada anak yang menanggapi pembicaraan anak. Telah disampaikan terdahulu, bahwa selama perkembangan anak terus mendapat pengaruh-pengaruh dari luar maka demikian pula dengan perkembangan bicara dan bahasa, tanpa pengaruh yang mengarah kepada kesempurnaan, tak akan terjadi bicara yang benar dan teratur bagi anak. Katakan bahwa anak itu akan dapat berbicara kalau lingkungan memberi kesempatan untuk mengem-bangkan potensi bicaranya. Anak dapat berbicara dengan baik kalau ada pada lingkungan yang berbicara baik, sebaliknya bicara mereka kurang baik, bila tiap waktu hanya mendengar kata-kata yang kurang baik pula.

Seorang anak yang belum berusia lima tahun masih berbicara seperti bayi, atau tampak ucapan yang salah, itu masih dikatakan normal. Tetapi kalau sudah berumur lima tahun lebih mengucapkan kata-kata yang tidak jelas dan dapat berbicara pun tapi tidak jelas dapat dipastikan bisa mengalami cacat bicara (speech defect). Bicara dikatakan cacat jika kata-kata yang dikeluarkan oleh alat ucap anak itu menarik perhatian, tidak mudah dipahami dan tidak enak didengar. Maksudnya bahwa bicara 
itu tidak sempurna kalau menyimpang sangat jauh dari model pembicaraan pada umumnya. $^{12}$

\section{Integrasi Kemampuan Literasi dengan Metode Dongeng}

Kemampuan literasi terdiri dari 3 kemampuan bahasa yakni, kemampuan berbicara, kemampuan membaca dan kemampuan menuli. Ketiga komponen dari kemampuan literasi ini satu sama lain memiliki keterkaitan dan tidak bisa berdiri sendiri. Seseorang ketika berupaya mengembangkan salah satu komponen dari kemampuan literasi secara otomatis komponen lainnya akan ikut terasah. Misalnya seorang siswa belajar membaca, ketika prosesnya secara tidak langsung siswa tersebut melatih kemampuan berbicara dan pada saat membaca siswa pun mengikuti apa yang diucapkannya kedalam tulisa.

Guru yang telah terbiasa menggunakan metode mendongeng (berbeda dengan ceramah) pada saat proses KBM pada umumnya pasti memiliki siswa yang berkemampuan literasi yang baik dibandingkan dengan guru yang hanya mengajar dengan cara konvensional di dalam kelas.Kebiasaan yang di timbulkan dari aktivitas mendongeng mampu memberikan banyak dampak positif terhadap kemampuan literasi siswa baik kemampuan membaca, menulis dan berbcara. Berikut adalah dampak positif yang dari kegiatan mendongeng:

a. Aktivitas mendongeng mampu mendukung proses pengembangan kemampuan membaca siswa.

Kegiatan mendongeng yang disajikan oleh guru pada saat kegiatan pembelajaran mampu meningkatkan minat baca siswa. Seorang guru dapat membimbing para siswanya untuk membaca dengan mengajak siswanya membaca buku dongeng. Guru memiliki kuasa penuh dalam aktifitas ini, dimana seorang guru mengaarahkan siswanya membaca dengan mengkemas sedemikian rupa rangkaian kegiatan membaca buku dongeng bersama.

\footnotetext{
${ }^{12}$ Suci rahmadani. 2015. Upaya meningkatkankemampuan menceritakan kembali melalui metode mendongeng. Sekolah guru Indonesia. Gorontalo
} 
b. Aktivitas mendongeng mampu mendukung proses pengembangan kemampuan menulis siswa.

Kegiatan mendongeng yang dilakukan oleh guru di kelas bisa diintegrasikan dengan kegiatan menulis cerita. Kegiatan ini selain melatih kemampuan imajinasi yang dimiliki siswa, kegiatan menuliskan kembali cerita juga mampu mengembangkan kemampuan menulis yang dimiliki siswa terutama bagi siswa kelas 4 yang sudah diharuskan memiliki kemampuan menuliskan cerita.

c. Aktivitas mendongeng mampu mendukung proses pengembangan kemampuan berbicara siswa.

Kegiatan mendongeng merupakan kegiatan bercerita kisah atau kejadian baik yang dialami diri sendiri maupun yang dialami oleh orang lain. Kegiatan mendongeng tentu sangat erat sekali kaitannnya dengan kemampuan berbicara, bukan dikatakan mendongeng kalau tidak berbicara.

\section{Kesimpulan}

Guru yang kreatif tentu tidak akan kehabisan cara untuk mengembangkan kemampuan berbicara siswa. Terlebih kemampuan berbicara terintegrasi dengan aspek kepercayaan diri yang dimiliki siswa. Sangat sulit bagi seorang guru untuk mengembangkan kemampuan berbicara siswa yang memiliki rasa percaya diri yang rendah (minim). Seorang guru bisa menggunakan metode mendongeng untuk mengembangkan kemampuan berbicara siswa tanpa harus terkendala dengan rasa percaya yang dimiliki siswa. Hal ini dikarenakan kegiatan mendongeng atau bercerita sangat ringan bagi siswa untuk dilakukan. Secara bertahap dan berkelanjutan kegiatan mendongeng ini mampu mengembangkan kemampuan berbicara atau yang biasa kita kenal dengan skill of public speaking

\section{DAFTAR PUSTAKA}

Departemen Pendidikan dan Kebudayaan. 2001. Kamus Besar Bahasa Indonesia. Jakarta: Balai Pustaka 
http://www.antaranews.com/berita/462239/psikolog-stimulasi-kemampuan-literasisejak-dini-penting

Mubarak, hasan. Integrasi kemampuan berbahasa dalam proses pengembangan kemampuan menulis. Jakarta. 2010

Shakuntala Devi. 2002. Bangunkan Kejeniusan Anak Anda. Jakarta: Gramedia

Shauqi, akhmad. "upaya meningkatkan keterampilan membaca siswa melalui pendekatan whole language. Gorontalo.2015

Suci rahmadani. 2015. Upaya meningkatkankemampuan menceritakan kembali melalui metode mendongeng. Sekolah guru Indonesia. Gorontalo

Sukatmi.2009. Upaya Meningkatkan Keterampilan Berbicara dengan Media Gambar. Tidak Dipublikasikan. Skripsi Universitas Sebelas Maret.

Yunus Maulana. 2008. Mudahnya menulis, ayo menulis. Bumi Aksara. Yogyakarta 